\title{
Odpowiedzialność osób trzecich z tytułu składek na ubezpieczenia społeczne - wybrane problemy orzecznicze
}

\section{Remission of social security contributions in the light of the jurisprudence of administrative courts}

Streszczenie. Przedmiotem opracowania jest analiza orzeczeń sądowych dotyczących odpowiedzialności osób trzecich odpowiadających za zobowiązania płatnika składek na ubezpieczenia społeczne oraz zobowiązania podatkowe, która ma zmierzać do ustalenia, czy i w których obszarach występują rozbieżności w orzecznictwie sądów powszechnych oraz sądów administracyjnych oraz ocena poszczególnych linii orzeczniczych. Analiza orzeczeń sądów dotyczących odpowiedzialności członków zarządu jako osób trzecich prowadzi do wniosku, że w związku ze stosowaniem przepisów przewidujących tę odpowiedzialność powstają liczne problemy, co skutkuje powstaniem rozbieżności w orzecznictwie. $\mathrm{Z}$ analizy poszczególnych linii orzeczniczych wynikają różnice w rozstrzygnięciach sądów powszechnych i wyrokach sądów administracyjnych, a także różnice w ramach orzecznictwa poszczególnych sądów. Sytuacja ta stwarza stan niepewności po stronie podmiotów zobowiązanych oraz skutkuje wydawaniem odmiennych wyroków w tych samych stanach faktycznych. Podkreślić przy tym należy, 
że w świetle przesłanek odpowiedzialności stabilniej prezentuje się orzecznictwo SN, a rozbieżność linii orzeczniczych w przeważającej części dotyczy orzecznictwa sądów administracyjnych.

Słowa kluczowe: składki na ubezpieczenia społeczne; odpowiedzialność prawna; osoby trzecie; członkowie zarządu spółek kapitałowych.

\begin{abstract}
This article aims to analyse judicial decisions concerning the liability of third parties who are responsible for the liability of the payer of social security contributions and tax liabilities. The aim is to determine whether and in which areas there are discrepancies in the decisions of common courts and administrative courts and the assessment of individual lines jurisprudence. The author reviewed judicial decisions in this area and he attempted to determine the distinct lines of interpretation. Analysis of court decisions leads to the conclusion that rules requiring that responsibility are applied in a divergent way. In the author's opinion this situation creates a state of uncertainty for entities that are required.
\end{abstract}

Keywords: contributions to social insurance; legal liability; liability of third parties; member of the board of the capital company.

\title{
1. Wstęp
}

Odpowiedzialność osób trzecich z tytułu składek na ubezpieczenia społeczne płatnika stanowi instytucję, która z uwagi na swoją istotę (odpowiedzialność za zobowiązania innego podmiotu) oraz jakość regulujących ją przepisów wzbudza spory zarówno w doktrynie prawa finansów publicznych, jak i w praktyce. Uzasadnia to prowadzenie badań nad tą instytucją, w tym konieczność analizy orzecznictwa sądowego. W związku z poddaniem kontroli nad przestrzeganiem przez organy administracyjne przepisów regulujących odpowiedzialność osób trzecich w odniesieniu do należności z tytułu składek na ubezpieczenie społeczne sądom powszechnym, natomiast co do zobowiązań podatkowych sądom administracyjnym, szczególnie interesujące wydają się przy tym ewentualne różnice w wykładni przepisów dokonywanej przez te sądy. Problem ten jest istotny, biorąc pod uwagę możliwość wystąpienia sytuacji, w której ta sama osoba zobowiązana ma status osoby trzeciej w związku z odpowiedzialnością za 
zaległości podatkowe (często w kilku podatkach) i jednocześnie z tytułu składek na ubezpieczenia społeczne. Pojawia się wówczas ryzyko sytuacji, w której orzeczenia sądów powszechnych oraz administracyjnych $\mathrm{w}$ takim samym stanie faktycznym będą rozbieżne $\mathrm{z}$ uwagi na odmienną wykładnię tych samych przepisów. Przedmiotem niniejszego opracowania jest analiza orzeczeń sądowych dotyczących odpowiedzialności osób trzecich zmierzająca do ustalenia, czy i ewentualnie w których obszarach występują powyższe rozbieżności oraz ocena poszczególnych linii orzeczniczych.

Zaznaczyć należy, że z uwagi na ramy opracowania, analizując

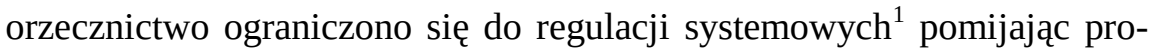
blem należności z tytułu składek ubezpieczeniowych rolników. Jednocześnie w związku z szerokim katalogiem osób trzecich odpowiadających za zobowiązania jako przedmiot analiz wybrano regulacje prawne dotyczące członków zarządu spółek kapitałowych, które w praktyce są stosowane najczęściej.

\section{Regulacje prawne dotyczące odpowiedzialności osób trzecich za zobowiązania z tytułu składek}

Za składki na ubezpieczenie społeczne co do zasady odpowiadają płatnicy składek wskazani w ustawie systemowej (art. 17 ust. 1 u.s.u.s.). Jednocześnie, podobnie jak w wypadku zobowiązań podatkowych, ustawodawca przewidział możliwość odpowiedzialności osób trzecich za zobowiązania płatników tych składek. Zgodnie z art. 31 ust. 1 u.s.u.s. do należności z tytułu składek stosuje się odpowiednio przepisy dotyczące zobowiązań podatkowych w tym m.in. art. 107 § 1, 1a, § 2 pkt 2 i 4 i § 3, art. 108 § , 3 i 4, art. 109 § 1 w zakresie art. 29, art. 109 § 2 pkt 1, art. 110 § 1, § 2 pkt 2, § 3, art. 111 § 1-4 i § 5 pkt 1, art. 112 § 1-5, art. 112b, art. 112c, art. 113, art. 114, art. 115-117, art. 118 oraz art. 119 ustawy z dnia 29 sierpnia

Ustawa z dnia 13 października 1998 r. o systemie ubezpieczeń społecznych (tekst jedn.

Dz.U. z 2016 r., poz. 963 ze zm.), dalej: u.s.u.s. lub ustawa systemowa. 
1997 r. - Ordynacja podatkowa ${ }^{2}$. Powołane przepisy o.p. wskazują osoby trzecie odpowiadające za zaległości podatkowe podatnika oraz regulują zasady ich odpowiedzialności. Zgodnie z art. 107 o.p. w zw. z art. 31 u.s.u.s. zakres przedmiotowy odpowiedzialności osób trzecich obejmuje zaległości składkowe, odsetki za zwłokę, a także koszty postępowania egzekucyjnego. Podmiotami odpowiadającymi jako osoby trzecie za zobowiązania z tytułu składek na ubezpieczenia społeczne są z kolei: rozwiedziony małżonek, członek rodziny współdziałający w prowadzeniu działalności gospodarczej, nabywca przedsiębiorstwa lub jego zorganizowanej części, jednoosobowa spółka kapitałowa powstała w wyniku przekształcenia przedsiębiorcy będącego osobą fizyczną, spółka niemająca osobowości prawnej, do której osoba fizyczna wniosła na pokrycie udziału swoje przedsiębiorstwo, firmujący, podmiot oddający do korzystania rzecz lub prawo majątkowe, wspólnicy spółek osobowych, członkowie zarządu spółek kapitałowych oraz innych osób prawnych, likwidatorzy spółki oraz osoby prawne przejmujące inne osoby prawne w wyniku podziału.

Celem instytucji odpowiedzialności osób trzecich jest zabezpieczenie interesu wierzyciela zobowiązania publicznoprawnego w sytuacji, gdy wyegzekwowanie należności od zobowiązanego jest utrudnione lub niemożliwe ${ }^{3}$. Wyznaczając krąg osób trzecich, ustawodawca posługuje się kryterium ekonomicznego związku dłużników i osób trzecich, który jednocześnie nie zawsze wiąże się z korzyściami, które osoby trzecie uzyskują kosztem wierzyciela ${ }^{4}$.

Zgodnie z art. 91 o.p. do odpowiedzialności solidarnej za zobowiązanie podatkowe stosuje się przepisy kodeksu cywilnego dla zobowiązań cywilnoprawnych. Z kolei w myśl art. 366 ustawy z 23 kwietnia 1964 r. Kodeks cywilny ${ }^{5}$ kilku dłużników może być zobowiązanych w ten sposób, że wierzyciel może żądać całości lub części świadczenia od wszyst-

Tekst jedn. Dz.U. z 2017 r., poz. 201 ze zm., dalej: o.p.

B. Brzeziński, Zobowiq̨zanie podatkowe w świetle orzecznictwa sq̨dów, Toruń 1993, s. 74.

4 A. Olesińska, Odpowiedzialność osób trzecich w Ordynacji podatkowej, [w:] B. Brzeziński, C. Kosikowski (red.), Ordynacja podatkowa. Studia, Łódź-Toruń 1999, s. 115.

$5 \quad$ Tekst jedn. Dz.U z 2017 r., poz. 459 ze zm., dalej: k.c. 
kich dłużników łącznie, od kilku z nich lub od każdego z osobna, a zaspokojenie wierzyciela przez któregokolwiek z dłużników zwalnia pozostałych. Z uwagi na to, że egzekucja w stosunku do osoby trzeciej może być wszczęta dopiero wówczas, gdy egzekucja z majątku zobowiązanego okazała się bezskuteczna, odpowiedzialność ma charakter subsydiarny.

W związku z treścią art. 123 u.s.u.s. postępowanie w przedmiocie odpowiedzialności osoby trzeciej z tytułu należności z tytułu składek na ubezpieczenia społeczne toczy się na podstawie przepisów ustawy z 14 czerwca 1960 r. - Kodeks postępowania administracyjnego ${ }^{6}$.

Ponieważ w przepisach o.p. użyto terminu „odpowiedzialność osoby trzeciej”, wyjaśnienia wymaga również rozumienie terminu „odpowiedzialność prawna”. Odpowiedzialność prawna to opracowana przez doktrynę komplementarna do stosunku prawnego konstrukcja myślowa, na którą składa się zespół pojęć normatywnych ${ }^{7}$. Samo pojęcie odpowiedzialności funkcjonuje jednocześnie w większości gałęzi prawa również na gruncie normatywnym. Brak jest jednak precyzyjnego określenia w treści przepisów tej instytucji, co powoduje, że prowadząc analizę odpowiedzialności, konieczne jest każdorazowe odwołanie do ustaleń doktryny $^{8}$. W literaturze odpowiedzialność prawną definiuje się jako zasadę ponoszenia przewidzianych prawem ujemnych konsekwencji za zdarzenia lub stany rzeczy podlegające ujemnej kwalifikacji normatywnej i przypisywane prawnie określonemu podmiotowi w danym porządku prawnym ${ }^{9}$. Tak rozumiana odpowiedzialność prawna obejmuje zespół różnorodnych instytucji prawnych, które znajdują zastosowanie w sytuacji zaistnienia stanu rzeczy niezgodnego z treścią normy prawnej. Odpowiedzialność prawna pełni tym samym funkcję kompensacyjną, przywracając równo-

$6 \quad$ Tekst jedn. Dz.U. z 2016 r. poz. 23 ze zm., dalej: k.p.a. Rozwiązanie to jest spójne z treścią art. $180 \S 1$ k.p.a., który przewiduje, że w sprawach z zakresu ubezpieczeń społecznych stosuje się przepisy tego kodeksu, chyba że przepisy dotyczące ubezpieczeń ustalają odmienne zasady postępowania.

7 Tak W. Lang, Rozdział 18. Pojęcia prawne i prawnicze, [w:] W. Lang, J. Wróblewski, S. Zawadzki, Teoria państwa i prawa, Warszawa 1986, s. 385.

8 Zob. np. M. Gintowt-Jankowicz, Odpowiedzialność podatkowa w obowiq̨zujq̨cym prawie polskim, „, Studia Prawnicze” 1973, nr 35, s. 117-119.

9 Tak W. Lang, Struktura odpowiedzialności prawnej, „Zeszyty Naukowe Uniwersytetu Mikołaja Kopernika w Toruniu. Prawo” 1968, t. VIII, nr 31, s. 12. 
wagę porządku prawnego naruszoną bezprawnymi działaniami ${ }^{10}$. Dla potrzeb prowadzonych badań na gruncie poszczególnych gałęzi prawa możliwe jest jednocześnie rozszerzenie zakresu pojęcia odpowiedzialności poprzez przyjęcie, że obejmuje ona wszystkie konsekwencje związane z nałożeniem obowiązków przez normę prawną na podmiot zobowiązany, tj. bez ograniczenia się do negatywnych konsekwencji niewykonania tych obowiązków. Typowym przykładem jest nauka prawa podatkowego, w której wyróżnia się i analizuje odpowiedzialność za zobowiązania podatkowe ${ }^{11}$. W taki sam sposób należy również rozumieć odpowiedzialność osób trzecich za należności z tytułu składek na ubezpieczenie społeczne.

\section{Przesłanki odpowiedzialności członków zarządu spółek kapitałowych}

Zgodnie z art. 116 § 1 o.p. za zaległości podatkowe spółki z ograniczoną odpowiedzialnością, spółki z ograniczoną odpowiedzialnością w organizacji, spółki akcyjnej lub spółki akcyjnej w organizacji odpowiadają solidarnie całym swoim majątkiem członkowie jej zarządu, jeżeli egzekucja z majątku spółki okazała się w całości lub w części bezskuteczna, a członek zarządu:

1) nie wykazał, że we właściwym czasie zgłoszono wniosek o ogłoszenie upadłości lub w tym czasie zostało otwarte postępowanie restrukturyzacyjne w rozumieniu ustawy z dnia 15 maja 2015 r. - Prawo restrukturyzacyjne $^{12}$ albo zatwierdzono układ w postępowaniu o zatwierdzenie układu, o którym mowa w ustawie z dnia 15 maja 2015 r. - Prawo restrukturyzacyjne, albo niezgłoszenie wniosku o ogłoszenie upadłości nastąpiło bez jego winy;

\footnotetext{
Tamże, s. 23.

Zob. B. Brzeziński, Zobowiq̨zania podatkowe..., s. 65; A. Mariański, Odpowiedzialność za zobowiqzzania podatnika, płatnika, inkasenta w prawie polskim, Warszawa 1999, s. 13-15; W. Olszowy, Niektóre zagadnienia prawne odpowiedzialności podatkowej, „Acta Universitatis Lodziensis. Folia Iuridica” 1992, nr 54, s. 86-88.

12 Tekst jedn. Dz.U. z 2016, poz. 1574.
} 
2) nie wskazuje mienia spółki, z którego egzekucja umożliwi zaspokojenie zaległości podatkowych spółki w znacznej części.

Odpowiedzialność członków zarządu obejmuje zaległości podatkowe z tytułu zobowiązań, których termin płatności upływał w czasie pełnienia przez nich obowiązków członka zarządu. Przedstawiciele doktryny, oceniając powołane regulacje prawne, wskazują na chaotyczną ewolucję tej instytucji prawnej bazującej na wzorcu z zakresu prawa handlowego, która jest ściśle związana ze zmianami ustrojowo-gospodarczymi ${ }^{13}$. Odmienny $\mathrm{w}$ porównaniu z pozostałymi osobami trzecimi jest cel tej odpowiedzialności, którym jest wymuszenie właściwego wykonywania przez członków zarządu ich obowiązków ${ }^{14}$ na co wskazuje m.in. brak ograniczenia wysokości kwoty, za jaką odpowiada członek zarządu spółki. W porównaniu z odpowiedzialnością innych osób trzecich, odmienne znaczenie ma także przesłanka „bezskuteczności egzekucji”, która w wypadku członków zarządu spółek kapitałowych warunkuje w ogóle możliwość odpowiedzialności osoby trzeciej, a nie wyłącznie wskazuje na subsydiarny charakter tej instytucji. Charakterystyczne jest również to, że w treści przepisów regulujących odpowiedzialność członków zarządu spółek kapitałowych występują pojęcia niedookreślone - „właściwy czas” oraz „znaczna część”. Specyficzne jest także to, że w wypadku odpowiedzialności członków zarządu spółek kapitałowych istnieje możliwość wyłączenia ich odpowiedzialności w sytuacji wykazania zaistnienia przesłanek egzoneracyjnych i związany z tym problem przerzucenia „ciężaru dowodowego" oraz odwołanie do kategorii winy, które w regulacjach prawa daninowego stanowią rzadkość.

Stosowanie regulacji dotyczących odpowiedzialności jako osób trzecich członków zarządu spółek kapitałowych wywołuje liczne wątpliwości, prowadząc do rozbieżności w orzecznictwie, w tym opisanych w dalszej części opracowania rozbieżnych linii orzeczniczych sądów powszechnych oraz administracyjnych.

13 A. Olesińska, Odpowiedzialność osób trzecich za zobowiqzania podatkowe, Lublin 2000, s. 117.

14 A. Mariański, Odpowiedzialność osób trzecich za zobowiq̨zania. Podstawy i wyłązenia, Gdańsk 2004, s. 104. 


\section{Skutki procesowe solidarnego charakteru odpowiedzialności osoby trzeciej}

W związku z solidarnym charakterem odpowiedzialności osoby trzeciej w orzecznictwie pojawiły się wątpliwości dotyczące skutków procesowych związanych z treścią wydanej decyzji oraz jej doręczeniem.

Pierwszym problemem jest kwestia obowiązku wyraźnego wskazania w decyzji, że odpowiedzialność osób trzecich jest solidarna. Zgodnie z uchwałą SN z 16 kwietnia 2014 r. ${ }^{15}$ decyzja ZUS ustalająca odpowiedzialność członka zarządu spółki z o.o. za zaległości składkowe spółki nie musi zawierać wskazania, że odpowiedzialność ta jest solidarna z innymi członkami zarządu, co do których zostały wydane odrębne decyzje. Wskazać należy, że pogląd powyższy przed podjęciem uchwały nie był podzielany przez wszystkie sądy powszechne. Przykładowo w wyroku SA w Łodzi z 27 czerwca 2013 r. ${ }^{16}$ solidarny charakter odpowiedzialności danego dłużnika powinien być jednoznacznie sformułowany w rozstrzygnięciu decyzji, w przeciwnym razie nie ma pewności respektowania zasady, iż zaspokojenie wierzyciela przez któregokolwiek z dłużników zwalnia pozostałych.

Z kolei w orzecznictwie sądów administracyjnych kwestia ta nie wywoływała wątpliwości, ponieważ jakkolwiek wskazywano na celowość zamieszczenia informacji o solidarności zobowiązania, to jednolicie uznawano, że brak wyraźnego stwierdzenia w rozstrzygnięciu decyzji, że dany członek zarządu spółki odpowiada solidarnie z pozostałymi członkami tego zarządu i ze spółką za zaległości spółki, nie może stanowić wystarczającej podstawy uchylenia tej decyzji, a tym bardziej do stwierdzenia jej nieważności ${ }^{17}$. Pogląd ten należy w pełni podzielić.

Kolejny problem związany z solidarnością zobowiązania stanowi możliwość dokonania wyboru przez organ podmiotu odpowiadającego jako osoba trzecia na etapie wydania decyzji. Wątpliwości wywołuje bo-

\footnotetext{
Sygn. I UZP 2/13.

Sygn. III AUa 1513/12; podobnie wyrok SA w Krakowie z 3 września 2013 r., sygn. III AUa 537/12.

Wyrok NSA z 3 lipca 2014 r., sygn. I FSK 1274/13.
} 
wiem to, czy organ może, czy też musi wydać decyzję o odpowiedzialności wszystkich członków zarządu. Powstanie wątpliwości wynika m.in. z tego, że art. 31 u.s.u.s. nie odsyła do odpowiedniego stosowania art. 92 § 1 o.p., zgodnie z którym jeżeli, według ustaw podatkowych, podatnicy ponoszą solidarną odpowiedzialność za zobowiązania podatkowe, a zobowiązania te powstają w sposób przewidziany w art. $21 \S 1$ pkt 2 o.p., odpowiedzialnymi solidarnie są podatnicy, którym doręczono decyzję ustalającą wysokość zobowiązania podatkowego. Z przepisu wynika zatem, że ustawodawca dopuszcza możliwość wydania decyzji, która nada status zobowiązanego solidarnie wyłącznie wybranym podmiotom. W odniesieniu do osób trzecich odpowiadających za należności z tytułu składek należy stwierdzić, że problem powyższy został rozstrzygnięty, ponieważ SN w uchwale z 15 października 2009 r. ${ }^{18}$ stwierdził, że decyzja organu rentowego o przeniesieniu na członków zarządu spółki prawa handlowego odpowiedzialności za zaległości spółki z tytułu składek na ubezpieczenia społeczne powinna być wydana wobec wszystkich członków zarządu, którzy pełnili tę funkcję w czasie powstania zaległości składkowych. W wyroku SN z 4 października 2011 r. ${ }^{19}$ dodano natomiast, że w przypadku oceny przez organ rentowy, iż jeden z członków zarządu nie ponosi odpowiedzialności za zaległości składkowe, konieczne jest zawarcie tego stwierdzenia w decyzji obejmującej odpowiedzialnością pozostałych członków zarządu spółki.

W orzecznictwie sądów administracyjnych problem konieczności doręczenia decyzji o odpowiedzialności wszystkich członków zarządu był rozstrzygany niejednolicie. Przykładowo w wyroku NSA z 11 stycznia 2006 r. $^{20}$ uznano, że organ podatkowy może wszcząć postępowanie przeciwko jednemu z członków zarządu spółki akcyjnej i wydać w stosunku do niego decyzję, jeżeli zachodzą przesłanki z art. 116 o.p. W ocenie sądu udział innych członków zarządu w tym postępowaniu nie jest konieczny i zależy jedynie od ich woli. Wątpliwości rozstrzygnięto w uchwale NSA

\footnotetext{
Sygn. I UZP 3/09.

Sygn. I UK 1113/11.

Sygn. II FSK 140/05.
} 
z 9 marca 2009 r. $^{21}$, w której jednoznacznie przesądzono, że przepis art. $116 \S 1$ o.p. nakłada na organ podatkowy obowiązek prowadzenia postępowania w przedmiocie odpowiedzialności za zaległości podatkowe spółki z o.o. wobec wszystkich osób mogących ponosić taką odpowiedzialność. Należy jednocześnie stwierdzić, że kwestia ta w orzecznictwie nie jest obecnie przesądzona we wszystkich możliwych sytuacjach, ponieważ pojawiają się orzeczenia dotyczące problemu solidarności w analogicznych sytuacjach (współwłaściciele nieruchomości jako zobowiązani solidarnie podatnicy podatku od nieruchomości ${ }^{22}$ ), w których odstępuje się obowiązku doręczenia decyzji wszystkim solidarnie zobowiązanym podmiotom. Przykładowo zgodnie z wyrokiem NSA z 24 listopada 2016 r. ${ }^{23}$ organ podatkowy, ustalając zobowiązanie podatkowe w stosunku do niektórych tylko współwłaścicieli nieruchomości, korzysta jedynie z ustawowego uprawnienia wierzyciela podatkowego zgodnie $\mathrm{z}$ zawartym w przedmiotowym akcie prawnym odesłaniem do zasady solidarności zobowiązań ujętej w k.c. Sąd uznał, że organ ma wobec tego prawo ustalić zobowiązanie podatkowe w stosunku do wszystkich lub niektórych tylko współwłaścicieli w sytuacji, gdy brak możliwości ustalenia wszystkich współwłaścicieli danej nieruchomości. Pogląd powyższy wyrażony w specyficznym stanie faktycznym (podjęto próbę ustalenia kilkudziesięciu podatników i doręczenia im decyzji) nie powinien być jednocześnie uznawany jako odejście od wyrażonej w powołanej wyżej uchwale NSA zasady doręczania decyzji wszystkim podmiotom zobowiązanym osobom trzecim.

\section{Problem przeniesienia na członka zarządu „ciężaru dowodowego"}

W związku z zawartymi w treści art. 116 § 1 o.p. przesłankami wyłączającymi odpowiedzialność członka zarządu powstaje wątpliwość, czy jed-

\footnotetext{
Sygn. I FPS 4/08.

Zob. art. 3 ust. 4 ustawy z 12 stycznia 1991 r. o podatkach i opłatach lokalnych (tekst jedn. Dz.U. z 2016 r., poz. 716 ze zm.).

23 Sygn. II FSK 3146/14.
} 
nocześnie przepis ten przewiduje przeniesienie na członka zarządu ciężaru dowodowego w zakresie wykazania przesłanek uwalniających od odpowiedzialności. Wątpliwość powstaje w związku z istotą postępowania podatkowego, które co do zasady wyklucza obowiązek dowodzenia przez podatnika jakichkolwiek okoliczności faktycznych, jakkolwiek podatnik, nie przedstawiając dowodów, które nie są w posiadaniu organu, musi liczyć się z ewentualnym negatywnym skutkiem prawnym. Zasadę tę należy również odnieść do postępowania administracyjnego toczącego się na podstawie przepisów k.p.a. Nie do końca jest także jasne sformułowanie art. $116 \S$ pkt 1 o.p. przewidującego odpowiedzialność członka zarządu, jeżeli „nie wykazał, że” zgłosił wniosek o ogłoszenie upadłości we właściwym czasie lub nie zawinił w jego niezgłoszeniu. W doktrynie podnosi się, że art. 116 o.p. zmienia wyłącznie częściowo zasady ciężaru dowodowego, tzn. to członek zarządu ma wykazać istnienie przesłanek egzoneracyjnych, jednak gromadzenie materiału dowodowego musi nastąpić z inicjatywy i przez czynność organu administracji, zwłaszcza wtedy, gdy strona przedstawia niepełny materiał dowodowy ${ }^{24}$.

Kwestia przeniesienia ciężaru udowodnienia na członka zarządu nie wywołuje kontrowersji w orzecznictwie sądów powszechnych. Przykładowo zgodnie z wyrokiem SA w Białymstoku z 9 marca 2016 r. ${ }^{25}$ przesłanki materialnoprawne do obciążenia członka zarządu odpowiedzialnością za zaległości składkowe spółki muszą być spełnione już na dzień wydania decyzji organu rentowego, przy czym ciężar wykazania przesłanek pozytywnych ciąży na organie rentowym, natomiast ciężar wykazania okoliczności zwalniających członka zarządu od tej odpowiedzialności spoczywa na tym członku zarządu.

Z kolei w orzecznictwie sądów administracyjnych problem przerzucenia ciężaru dowodowego jest rozstrzygany niejednolicie. Początkowo sądy podzielały zaprezentowane wyżej stanowisko, wskazując, że z brzmienia art. 116 § 1 o.p. wynika wyraźnie, że ciężar dowodu spoczywa na członku zarządu. W ocenie sądów świadczyły o tym zawarte

\footnotetext{
A. Mariański, Odpowiedzialność osób trzecich..., s. 111.

Sygn. III AUa 932/12; podobnie wyrok SA w Łodzi z 27 czerwca 2013 r., sygn. III AUa 1513/12.
} 
w przepisie słowa „chyba, że członek zarządu wykaże, że”. Uznawano w związku z tym, że wobec tak wyraźnego brzmienia przepisu nieuprawnione jest interpretowanie art. 122 i art. 187 o.p. w kierunku nakładania na organ obowiązku działania z urzędu w celu wykazania okoliczności ekskulpujących członka zarządu ${ }^{26}$. Jednocześnie orzecznictwo sądowe nie jest jednolite. Przykładowo w wyroku NSA z 26 października 2005 r. ${ }^{27}$ stwierdzono, że przy przenoszeniu odpowiedzialności na członka zarządu na podstawie art. $116 \S 1$ o.p., ciężar dowodu uwolnienia się od odpowiedzialności spoczywa na tym członku, co nie oznacza jednak, że organy podatkowe zwolnione są z obowiązku dowodzenia wynikającego z przepisów postępowania podatkowego określonego w art. 122 i art. 187 § 1 o.p. Jeszcze dalej idzie WSA w Warszawie w wyroku z 18 marca 2014 r. $^{28}$, stwierdzając, że stosując szczególną instytucję odpowiedzialności osób trzecich organy podatkowe, winny dążyć do ustalenia prawdy obiektywnej, a nie poprzez przerzucenie ciężaru dowodowego na stronę orzekać jej odpowiedzialność za cudzy dług. Takie określenie ciężaru dowodowego może prowadzić do orzeczenia tej odpowiedzialności, mimo że zgodnie z istniejąca prawdą obiektywną takie przesłanki nie występują ${ }^{29}$.

\section{Znaczenie okoliczności faktycznego sprawowania funkcji członka zarządu spółki kapitałowej dla jego odpowiedzialności jako osoby trzeciej}

Kolejny problem orzeczniczy, w którym dostrzec można niejednolitość poglądów, dotyczy oceny, czy odpowiedzialność członka zarządu spółki kapitałowej jako osoby trzeciej warunkowana jest faktycznym pełnieniem funkcji i związanej z tym kwestii znaczenia wadliwości powołania na członka zarządu.

\footnotetext{
Tak np. wyrok NSA z 14 września 2005 r., sygn. FSK 2062/04.

Sygn. I FSK 192/05; podobnie wyrok NSA z 10 września 2014 r., sygn. II FSK 2256/12. Sygn. V SA/Wa 527/13.

Sąd powołał się jednocześnie na poglądy doktryny - A. Mariański, Glosa do wyroku NSA z 11.2.2003 r., I SA/Łd 1006/01, „Orzecznictwo Sądów Polskich” 2004, nr 5, s. 293.
} 
Zgodnie z wyrokiem SN z 1 marca 2016 r. ${ }^{30}$ w sytuacji wiążącego przesądzenia o skutecznej rezygnacji wnioskodawcy z funkcji jednoosobowego zarządu dłużnej spółki, bez istotnego znaczenia jest sporny status wnioskodawcy jako prokurenta podejmującego nadal rozmaite istotne czynności zarządu spółki, który nie jest podmiotem subsydiarnej odpowiedzialności za zaległości podatkowe ani składkowe dłużnej spółki. Podobnie w wyroku SN z 6 stycznia 2009 r. ${ }^{31}$, który jakkolwiek odnosi się do stowarzyszenia, to jego teza jest uniwersalna, uznano, że w razie gdy zarząd stowarzyszenia został powołany niezgodnie z przepisami, faktyczne pełnienie funkcji członka tego zarządu przez osobę ujawnioną w takim charakterze w KRS nie przesądza o odpowiedzialności tej osoby za składki nieuiszczone przez stowarzyszenie na podstawie art. 116a o.p. Należy powołać również wyrok SA w Gdańsku z 31 lipca 2013 r. ${ }^{32}$, w którym uznano, że osoba, która bez przymusu, groźby lub podstępu wyraziła zgodę na powołanie do zarządu spółki ze świadomością, że pełnić będzie jedynie rolę „figuranta”, a następnie godziła się na taki stan rzeczy, w pełni ponosi ryzyko działalności tej spółki i odpowiedzialność za nietrafne przedsięwzięcia gospodarcze, czy też działania na szkodę spółki osób dopuszczonych za jej zgodą do faktycznego zarządzania spółką. Reasumując, orzecznictwo dotyczące należności z tytułu składek przyjmuje formalne podejście odnośnie do oceny tego, czy członek zarządu odpowiada jako osoba trzecia.

Z kolei w orzecznictwie sądów administracyjnych podejście do kwestii faktycznego sprawowania funkcji członka zarządu nie jest jednolite. Część aktualnych wyroków prezentuje podejście ściśle formalne. Przykładowo NSA w wyroku z 30 września 2014 r. ${ }^{33}$ stwierdził, że przesłanka „pełnienia obowiązków członka zarządu” rozumiana jest formalnie, tj. jako posiadanie formalnych uprawnień członka zarządu za konkretny okres, niezależnie od tego, czy obciążony odpowiedzialnością członek zarządu faktycznie zajmował się interesami podmiotu, w którym był

\footnotetext{
Sygn. I UK 91/15.

Sygn. I UK 123/08.

Sygn. AUa 2181/12.

Sygn. FSK 1481/13.
} 
członkiem zarządu, i czy w ogóle posiadał taką możliwość. Jednocześnie istnieje linia orzecznicza wskazująca na konieczność oceny pomimo odwołania z funkcji członka zarządu, czy funkcja ta była lub nadal jest faktycznie wykonywana. Przykładowo w wyroku NSA z 14 czerwca $2016 \mathrm{r}^{34}$ stwierdzono, że zakres odpowiedzialności uregulowanej $\mathrm{w}$ art. 116 § 2 o.p. wyznacza pojęcie „pełnienia obowiązków członka zarządu”. W ocenie sądu pojęcie to należy odnosić do kontekstu faktycznego sprawy i nie można go sprowadzać tylko i wyłącznie do aspektów formalnych. Po wygaśnięciu mandatu członka zarządu należy mieć na względzie rzeczywistą zmianę sposobu zarządzania spółką. W sytuacji, gdy osoba dalej prowadzi sprawy spółki jako członek jej zarządu, chociaż jej mandat wygasł na mocy art. 202 § 1 ustawy z dnia 15 września 2000 r. - Kodeks spółek handlowych ${ }^{35}$, nie może skutecznie powołać się na tę okoliczność. W wyroku NSA z 18 listopada 2005 r. $^{36}$ stwierdzono, że odpowiedzialność osoby trzeciej, o której mowa w art. 116 § 2 o.p., nie może być skierowana wobec takiej osoby, która ani faktycznie nie pełniła obowiązków członka zarządu spółki, ani też nie miała możliwości pełnienia takich obowiązków w okresie, w którym powstały zaległości spółki.

Warto jednocześnie zwrócić uwagę na jednolite w orzecznictwie SN oraz NSA podejście do kwestii powoływania się przez członka zarządu przed sądem na wadliwe powołanie na tę funkcję, które nie zostało potwierdzone formalnie. Sądy odrzucają w takiej sytuacji możliwość uwolnienia się osoby trzeciej od odpowiedzialności. Przykładowo w wyroku SN z 23 września 2014 r. ${ }^{37}$ uznano, że wpisany do rejestru sądowego prezes (były prezes) spółki z o.o. nie może uwolnić się od subsydiarnej odpowiedzialności za jej długi składkowe na podstawie art. 116 o.p., ani zasadnie utrzymywać, że nie pełnił takiej funkcji, jeżeli nie wniósł powództwa przeciwko spółce o stwierdzenie nieważności uchwały zgromadzenia wspólników podjętej z naruszeniem zasady tajności wyboru (art. $247 \S 2$ w zw. z art. $252 \S 2$ k.s.h.), a podjęcie takiej uchwały nie miało

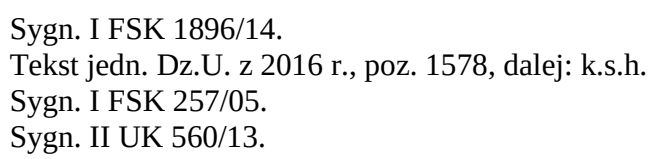


wpływu na jego wybór i sprawowanie funkcji prezesa dłużnej spółki.

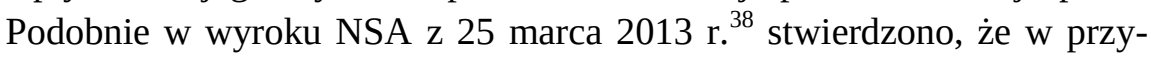
padku, gdy członek zarządu spółki z o.o. zarzuca, że zachodzi przesłanka uwalniająca go z odpowiedzialności z art. 116 o.p., a mianowicie twierdzi, że został powołany niezgodnie z prawem, to zgodnie z art. 252 § 1 k.s.h. powinien wnieść powództwo przeciwko spółce o stwierdzenie nieważności uchwały zgromadzenia wspólników spółki z ograniczoną odpowiedzialnością.

\section{7. „Wydanie” a „doręczenie” decyzji o odpowiedzialności członka zarządu spółki}

W orzecznictwie sądowym powstaje problem w związku z interpretacją art. 118 § 1 o.p., zgodnie z którym nie można wydać decyzji o odpowiedzialności podatkowej osoby trzeciej, jeżeli od końca roku kalendarzowego, w którym powstała zaległość podatkowa, upłynęło 5 lat. W kontekście ochrony praw strony wątpliwości wywołuje to, czy decyzja musi zostać wydana w znaczeniu również doręczona stronie przed upływem końca roku. W orzecznictwie SN oraz sądów powszechnych kwestia ta nie wywoływała wątpliwości. Przykładowo w wyroku SN z 16 listopada 2009 r. $^{39}$ oraz z 7 kwietnia 2010 r. $^{40}$ uznano jednoznacznie, że wydanie decyzji na podstawie art. 118 § 1 o.p. nie obejmuje obowiązku jej doręczenia.

Z kolei w orzecznictwie sądów administracyjnych kwestia ta wywołuje spory. Należy przy tym podkreślić, że zgodnie z uchwałą NSA z 17 grudnia $2007 \mathrm{r}^{41} \mathrm{w}$ stanie prawnym obowiązującym przed 1 stycznia 2003 r. pojęcie wydania decyzji określone w art. 118 § 1 o.p. nie oznaczało jej doręczenia. Jednocześnie ponieważ uchwała dotyczy przepisów obowiązujących przed 2003 r. w aktualnym orzecznictwie pojawiają się będące jednak w mniejszości - poglądy, zgodnie z którymi wykładnia językowa art. 118 § 1 o.p. prowadzi do wniosku, że pięcioletni okres

\footnotetext{
Sygn. I FSK 521/12.

Sygn. II UK 111/09.

Sygn. I UK 340/09.

Sygn. I FPS 5/07.
} 
przedawnienia, o którym mowa w tym przepisie, liczony od końca roku kalendarzowego, w którym powstała zaległość podatkowa przewidziany jest na „wydanie” decyzji o odpowiedzialności osoby trzeciej, a więc nadanie jej określonej przepisami formy, opatrzenie datą i doręczenie (art. 212 o.p.). Sądy stwierdzają, że decyzja wydana w trybie art. $116 \S 1$ o.p. jest decyzją konstytutywną, wymienioną w art. $21 \S 1$ pkt 2 o.p., a więc rodzącą powstanie obowiązku podatkowego, z momentem jej pojawienia się w obrocie prawnym, którym jest chwila doręczenia decyzji ${ }^{42}$. Na marginesie zaznaczyć należy, że problem rozumienia terminu „wydanie” decyzji o odpowiedzialności osoby trzeciej wiąże się z kolei opisaną wyżej kwestią solidarności zobowiązania i związanej z nią konieczności doręczenia decyzji wszystkim osobom trzecim.

\section{Wymóg bezskuteczności egzekucji jako przesłanka odpowiedzialności członka zarządu spółki}

Wątpliwości w orzecznictwie wywołuje także ocena przesłanki bezskuteczności egzekucji, która warunkuje odpowiedzialność członka zarządu spółki jako osoby trzeciej. Przykładowo w wyroku SN z 11 sierpnia 2016 r. $^{43}$ uznano, że bezskuteczność egzekucji w rozumieniu art. 116 o.p. jako przesłanka odpowiedzialności członka zarządu spółki nie musi być bezwzględnie stwierdzona postanowieniem o umorzeniu postępowania egzekucyjnego bezpośrednio przed wydaniem decyzji przenoszącej odpowiedzialność. Teza ta jest jednolicie obecnie przyjmowana w orzecznictwie w zakresie należności z tytułu składek.

W orzecznictwie sądów administracyjnych przyjmowano konieczność każdorazowego wszczęcia postępowania egzekucyjnego w celu ustalenia bezskuteczności, jednak występował brak jednolitości odnośnie do formalnego jej zakończenia, co skutkowało koniecznością wydania

\footnotetext{
42 Tak np. wyrok WSA w Gliwicach z 28 marca 2011 r. (sygn. I SA/Gl 526/10). Podobnie w wyroku WSA w Gliwicach z 1 lutego 2008 r. (sygn. III SA/Gl 1264/07) przyjęto, że pojęcie „wydania decyzji” w art. 118 § 1 o.p. obejmuje również doręczenie decyzji osobom trzecim. 
uchwały. Przykładowo w wyroku NSA z 27 lutego 2007 r. ${ }^{44}$ stwierdzono, że o bezskuteczności egzekucji powinien świadczyć formalny akt organu egzekucyjnego. Podobnie w wyroku WSA z 8 listopada 2006 r. ${ }^{45}$ stwierdzono, że jeżeli egzekucja jest prowadzona, to, co do zasady, ostateczny jej efekt w postaci jej bezskuteczności w stosunku do wierzyciela podatkowego może być w sposób definitywny stwierdzony dopiero po jej zakończeniu i wydaniu formalnego postanowienia kończącego postępowanie egzekucyjne. Na skutek istnienia rozbieżności w orzecznictwie wydana została uchwała NSA z 8 grudnia 2008 r. ${ }^{46}$, w której uznano, że stwierdzenie przez organ podatkowy bezskuteczności egzekucji, o której mowa w art. 116 § 1 o.p., powinno być dokonane po przeprowadzeniu postępowania egzekucyjnego. W ocenie sądu stwierdzenie bezskuteczności egzekucji ustala się natomiast na podstawie każdego prawnie dopuszczalnego dowodu. Na marginesie zaznaczyć należy, że po wydaniu uchwały zapadł wyrok, w którym uznano, że do uznania egzekucji za bezskuteczną nie wystarczy sama okoliczność niezaspokojenia roszczenia podatkowego, ponieważ w takiej sytuacji powinno być wydane odrębne postanowienie o bezskuteczności egzekucji ${ }^{47}$. Powołany wyrok zapadł jednocześnie w specyficznym stanie faktycznym, dlatego jego tezy nie należy uogólniać.

\section{Wpływ przedawnienia zobowiązania na toczące się postępowanie}

Wątpliwości natury procesowej wywołuje również problem przedawnienia zobowiązania członka zarządu spółki kapitałowej, która ma miejsce w trakcie toczącego się postępowania.

W orzecznictwie sądów administracyjnych kwestia ta nie wywoływała sporów. Przykładowo w wyroku WSA w Szczecinie z 8 czerwca 2016 r. $^{48}$ wygasanie zobowiązań podatkowych na skutek przedawnienia

\footnotetext{
Sygn. I FSK 46/06.

Sygn. III SA/Wa 3305/05.

Sygn. II FPS 6/08.

Tak wyrok NSA z 16 lutego 2012 r., sygn. II FSK 1565/10.

Sygn I SA/Sz 336/16.
} 
oznacza, że pomimo niezaspokojenia wierzyciela stosunek zobowiązaniowy przestaje istnieć z mocy prawa na podstawie art. 59 § 1 pkt 9 o.p. Wraz z upływem terminu przedawnienia stosunek prawny zobowiązania podatkowego wygasa bez względu na to, czy dłużnik podatkowy powoła się na nie, ponieważ przedawnienie uwzględniane jest z urzędu. Powyższe uwagi w ocenie sądu dotyczą wprawdzie zobowiązań podatkowych, lecz zgodnie z art. 31 u.s.u.s. - znajdują również odpowiednie zastosowanie do zobowiązań z tytułu składek na ubezpieczenie społeczne.

Z kolei w orzecznictwie sądów powszechnych oraz SN problem ten $\mathrm{W}$ odniesieniu do postępowania sądowego jest rozstrzygany odmiennie. W wyroku SN z 6 czerwca 2013 r. ${ }^{49}$ stwierdzono, że sąd rozpoznający odwołanie od decyzji ustalającej odpowiedzialność członka zarządu spółki z o.o. za zaległości składkowe tej spółki nie ma ani obowiązku, ani uprawnienia do badania kwestii przedawnienia zobowiązania wynikającego z tej decyzji. Podobnie w wyrokach SA w Poznaniu z 25 kwietnia $2013 \mathrm{r}^{50}$ oraz SN z 26 maja $2011 \mathrm{r} .{ }^{51}$ uznano, że w sprawie z odwołania od decyzji organu rentowego ustalającej odpowiedzialność członka zarządu spółki z o.o. za zaległości składkowe nie podlega rozpoznaniu kwestia przedawnienia należności z tytułu składek wynikających z tej decyzji na podstawie art. 24 ust. 5d u.s.u.s. Przepis ten aktualizuje się bowiem dopiero na etapie postępowania egzekucyjnego, czyli w sytuacji, gdy chodzi o wykonanie zobowiązania wynikającego z prawomocnej decyzji dotyczącej obciążenia osoby trzeciej. Jednocześnie zapadają wyroki, w których uznaje się, że kwestia przedawnienia w odniesieniu do decyzji dotyczącej wymiaru składek powinna być badana jako zarzut prawa materialnego $^{52}$. W związku z charakterem odpowiedzialności osób trzecich warunkowanych zasadami przewidzianymi w o.p. prawidłowa wydaje się właśnie ta ostatnia koncepcja.

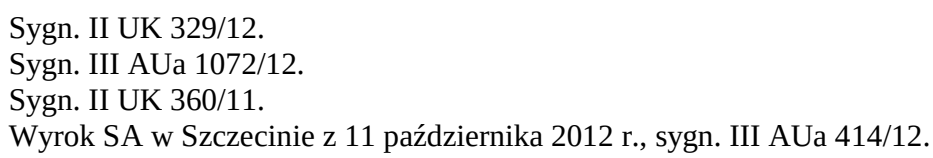




\section{Wnioski}

Analiza orzeczeń sądów dotyczących odpowiedzialności członków zarządu jako osób trzecich prowadzi do wniosku, że w związku ze stosowaniem przepisów regulujących tę odpowiedzialność powstają liczne problemy, co skutkuje rozbieżnymi orzeczeniami. W szczególności z analizy poszczególnych linii orzeczniczych wynikają różnice pomiędzy rozstrzygnięciami sądów powszechnych oraz SN a wyrokami sądów administracyjnych. Niejednolitość orzeczeń występuje także w ramach orzecznictwa poszczególnych sądów. Sytuacja ta stwarza stan niepewności po stronie podmiotów zobowiązanych oraz skutkuje wydawaniem odmiennych wyroków w tych samych stanach faktycznych ${ }^{53}$. Podkreślić przy tym należy, że w świetle przesłanek odpowiedzialności osób trzecich stabilniej prezentuje się orzecznictwo SN, a rozbieżność linii orzeczniczych w przeważającej części dotyczy orzecznictwa sądów administracyjnych. Największe wątpliwości wywołuje przy tym solidarny charakter zobowiązania osób trzecich, którego wynikiem są rozbieżne orzeczenia. Instytucja solidarnej odpowiedzialności dłużników ma bowiem swoje źródło w regulacjach prawa prywatnego, co wywołuje problemy w sytuacji jej stosowania w prawie finansów publicznych. Z kolei w kontekście różnic w ocenie konieczności przerzucenia ciężaru dowodowego oraz oceny skutków przedawnienia wydaje się, że przyczyną rozbieżności orzeczeń jest m.in. odmienny charakter procedury cywilnej oraz sądowoadministracyjnej. Powstaje także wątpliwość, czy część powstających problemów (m.in. ocena skutków przedawnienia) nie wynika z przyjęcia koncepcji odwołania w u.s.u.s. do regulacji o.p. połączona z niską ,jakością” przepisów ${ }^{54}$. Nie wydaje się jednocześnie celowe tworzenie odrębnych regulacji dotyczących osób trzecich odpowiadających za należności z tytułu składek w ustawie systemowej.

53 Zob. np. wyrok SN z 16 września 2009 r., sygn. I UK 277/08; na odmienną ocenę przez ten sam organ przesłanek warunkujących odpowiedzialność osób trzecich odpowiadających za zobowiązania podatkowe wskazuje wyrok WSA w Warszawie z 18 marca 2011 r., sygn. III SA/Wa 1782/10.

54 W. Morawski, Komentarz do art. 31 ustawy o systemie ubezpieczeń społecznych, [w:] J. Wantoch-Rekowski (red.), M. Bartoszewska, T. Brzezicki, J. Lachowski, A. Laskowska-Hulisz, M. Łabanowski, W. Morawski, A. Radzisław, L. Ramlo, Ustawa o systemie ubezpieczeń społecznych. Komentarz, Warszawa 2015, s. 364-365. 
Paweł Majka

\section{Bibliografia:}

Brzeziński B., Zobowiq̨zanie podatkowe w świetle orzecznictwa sq̨dów, TNOiK, Toruń 1993.

Gintowt-Jankowicz M., Odpowiedzialność podatkowa w obowiq̨zującym prawie polskim, „Studia Prawnicze” 1973, nr 35, s. 114-125

Lang W., Struktura odpowiedzialności prawnej, „Zeszyty Naukowe Uniwersytetu Mikołaja Kopernika w Toruniu. Prawo” 1968, t. VIII, nr 31, s. 10-32.

Lang W., Rozdział 18. Pojęcia prawne i prawnicze, [w:] W. Lang, J. Wróblewski, S. Zawadzki, Teoria państwa i prawa, PWN, Warszawa 1986.

Mariański A., Odpowiedzialność za zobowiqzania podatnika, płatnika, inkasenta w prawie polskim, Dom Wydawniczy ABC, Warszawa 1999.

Mariański A., Odpowiedzialność osób trzecich za zobowiq̨zania. Podstawy i wyłączenia, ODDK, Gdańsk 2004.

Mariański A., Glosa do wyroku NSA z 11.2.2003 r., I SA/Łd 1006/01, „Orzecznictwo Sądów Polskich” 2004, nr 5, s. 292-295.

Morawski W., Komentarz do art. 31 ustawy o systemie ubezpieczeń społecznych, [w:] J. Wantoch-Rekowski (red.), M. Bartoszewska, T. Brzezicki, J. Lachowski, A. Laskowska-Hulisz, M. Łabanowski, W. Morawski, A. Radzisław, L. Ramlo, Ustawa o systemie ubezpieczeń społecznych. Komentarz, LEX a Wolters Kluwer Business, Warszawa 2015.

Olesińska A., Odpowiedzialność osób trzecich w Ordynacji podatkowej, [w:] B. Brzeziński, C. Kosikowski (red. ), Ordynacja podatkowa. Studia, Łódź-Toruń 1999.

Olesińska A., Odpowiedzialność osób trzecich za zobowiq̨zania podatkowe, Lubelskie Wydawnictwa Prawnicze, Lublin 2000.

Olszowy W., Niektóre zagadnienia prawne odpowiedzialności podatkowej, „Acta Universitatis Lodziensis. Folia Iuridica” 1992, nr 54, s. 84-92. 